\title{
Gene Genealogies and AFLP Analyses in the Fusarium oxysporum Complex Identify Monophyletic and Nonmonophyletic Formae Speciales Causing Wilt and Rot Disease
}

\author{
Robert P. Baayen, Kerry O’Donnell, Peter J. M. Bonants, Elizabeth Cigelnik, \\ Laurens P. N. M. Kroon, Eugène J. A. Roebroeck, and Cees Waalwijk
}

\begin{abstract}
First, third, fifth, and seventh authors: Research Institute for Plant Protection, P.O. Box 9060, 6700 GW Wageningen, the Netherlands; second and fourth authors: National Center for Agricultural Utilization Research, U.S. Department of Agriculture, Agricultural Research Service, 1815 North University Street, Peoria, IL; and sixth author: Bulb Research Centre, P.O. Box 85, 2160 AB Lisse, the Netherlands. Current address of R. P. Baayen: Plant Protection Service, Mycology Section, P.O. Box 9102, 6700 HC Wageningen, the Netherlands. Current address of E. J. A. Roebroeck: Zeneca Mogen, P.O. Box 628, 2300 AP Leiden, the Netherlands.
\end{abstract}

Accepted for publication 5 May 2000.

\begin{abstract}
Baayen, R. P., O’Donnell, K., Bonants, P. J. M., Cigelnik, E., Kroon, L. P. N. M., Roebroeck, E. J. A., and Waalwijk, C. 2000. Gene genealogies and AFLP analyses in the Fusarium oxysporum complex identify monophyletic and nonmonophyletic formae speciales causing wilt and rot disease. Phytopathology 90:891-900.

The monophyletic origin of host-specific taxa in the plant-pathogenic Fusarium oxysporum complex was tested by constructing nuclear and mitochondrial gene genealogies and amplified fragment length polymorphism (AFLP)-based phylogenies for 89 strains representing the known genetic and pathogenic diversity in 8 formae speciales associated with wilt diseases and root and bulb rot. We included strains from clonal lineages of F. oxysporum f. spp. asparagi, dianthi, gladioli, lilii, lini, opuntiarum, spinaciae, and tulipae. Putatively nonpathogenic strains from carnation and lily were included and a reference strain from each of the three main clades identified previously in the $F$. oxysporum complex; sequences from related species were used as outgroups. DNA sequences from the nuclear translation elongation factor $1 \alpha$ and the mitochondrial small subunit (mtSSU) ribosomal RNA genes were combined for phylogenetic analysis.

Strains in vegetative compatibility groups (VCGs) shared identical sequences and AFLP profiles, supporting the monophyly of the two singleVCG formae speciales, lilii and tulipae. Identical genotypes were also found for the three VCGs in F. oxysporum f. sp. spinaciae. In contrast, multiple evolutionary origins were apparent for $F$. oxysporum f. spp. asparagi, dianthi, gladioli, lini, and opuntiarum, although different VCGs within each of these formae speciales often clustered close together or shared identical EF- $1 \alpha$ and mtSSU rDNA haplotypes. Kishino-Hasegawa analyses of constraints forcing the monophyly of these formae speciales supported the exclusive origin of $F$. oxysporum $\mathrm{f}$. sp. opuntiarum but not the monophyly of $F$. oxysporum f. spp. asparagi, dianthi, gladioli, and lini. Most of the putatively nonpathogenic strains from carnation and lily, representing unique VCGs, were unrelated to $F$. oxysporum f. spp. dianthi and lilii, respectively. Putatively nonpathogenic or rot-inducing strains did not form exclusive groups within the molecular phylogeny. Parsimony analyses of AFLP fingerprint data supported the gene genealogy-based phylogram; however, AFLP-based phylogenies were considerably more homoplasious than the gene genealogies. The predictive value of the forma specialis naming system within the $F$. oxysporum complex is questioned.
\end{abstract}

Fusarium oxysporum Schlechtend.: Fr. is an ubiquitous complex of cosmopolitan soilborne plant pathogens. Although a teleomorph is unknown, DNA sequence-based phylogenetic analyses place this complex unambiguously in the Gibberella clade, close to the $G$. fujikuroi species complex (36-39). Related species include F. nisikadoi (35), F. miscanthi (17), and F. redolens (39). Both $F$. oxysporum and $F$. redolens have been classified in Fusarium section Elegans Wollenw. (53) together with F. udum (19). However, the latter species is nested within the G. fujikuroi species complex, i.e., Fusarium section Liseola (39).

More than 150 host-specific formae speciales have been described in the F. oxysporum complex (FOC), each of them consisting of one or more vegetative compatibility groups (VCGs)

Corresponding author: R. P. Baayen; E-mail address: r.p.baayen@pd.agro.nl

Names are necessary to report factually on available data. However, the USDA neither guarantees nor warrants the standard of the product, and the use of the name implies no approval of the product to the exclusion of others that may also be suitable.

Publication no. P-2000-0615-01R

This article is in the public domain and not copyrightable. It may be freely reprinted with customary crediting of the source. The American Phytopathological Society, 2000. and often distinct pathogenic races. VCGs appear to represent clonal lineages and generally have unique restriction fragment length polymorphism (RFLP) and random amplified polymorphic DNA (RAPD) fingerprints $(3,6,24)$. While some formae speciales harbor a single VCG $(3,11,23,46)$, many comprise up to 10 or more VCGs, of which only a few are common and widespread. Katan (22) provides an overview of the current status of VCGs in the FOC. Population-genetic studies on this complex are mostly biased, because isolates from agricultural crops generally are investigated, resulting in an overestimation of clonality through human dissemination of infected propagative materials. Clonality is less common in putatively nonpathogenic populations (2), and some formae speciales harbor large numbers of VCGs, of which none is dominant (14). The same has been observed for $F$. proliferatum, a related species in the section Liseola with a rarely encountered teleomorph nested in the G. fujikuroi species complex (previously referred to as G. fujikuroi) $(13,19,29)$. Although a teleomorph has not yet been found, the sexual cycle may still be active in the FOC, in addition to parasexuality (47).

The genetic basis of host specificity (i.e., formae speciales) and cultivar specificity (i.e., pathogenic races) in the FOC is unknown. Nevertheless, a forma specialis is often assumed to have a single common ancestor from which all VCGs and races in that forma specialis have been derived (monophyly). Alternately, multiple 
VCGs and races within a given forma specialis could have multiple independent origins, with pathogenicity and virulence evolving more than once through mutation or transposition or spreading to distantly related strains through parasexuality or horizontal gene transfer. The monophyly hypothesis was recently tested by O'Donnell et al. (41) for four formae speciales, including $F$. oxysporum f. sp. cubense, causal agent of Panama disease of banana, by comparing DNA sequences of nuclear and mitochondrial genes. Concordant evidence from the respective gene genealogies revealed that $F$. oxysporum f. sp. cubense harbors at least five lineages with independent evolutionary origins (41). These phylogenetic analyses have been extended to $\approx 500$ strains from a wide range of formae speciales, resulting in two important discoveries: (i) $\approx 80 \%$ of formae speciales with two or more VCGs appear to be para- or polyphyletic; and (ii) the FOC possesses considerable phylogenetic structure, as evidenced by numerous clades in the gene genealogies (38) (K. O'Donnell, unpublished data).

The present study focused on the evolutionary relationships between VCGs from eight formae speciales associated with various rot and wilt diseases of flower bulbs, cacti, carnation, asparagus, flax, and spinach. Isolates representing all published VCGs and races were selected for the $F$. oxysporum f. spp. asparagi (eight VCGs), dianthi (six VCGs), gladioli (six VCGs), lilii (one VCG), spinaciae (three VCGs), and tulipae (one VCG) $(1,3,6,14$, $15,33,44)$. A wider range of isolates was selected from $F$. oxysporum f. spp. lini and opuntiarum, from which no VCGs had been identified. We included a reference strain from each of the three main clades, previously published in the FOC (41), and sequences from related species as outgroups. Gene genealogies were constructed from DNA sequences of translation elongation factor EF- $1 \alpha$, and the mitochondrial small subunit (mtSSU) ribosomal RNA genes and compared with independent phylograms from parsimony analyses of amplified fragment length polymorphism (AFLP) fingerprints. AFLP is a powerful tool in molecular fingerprinting and for studying relationships among isolates of fungi at the population, species, and supraspecific level $(9,32,42,49)$. Implications of the results of this study for the forma specialis naming system are discussed.

\section{MATERIALS AND METHODS}

Fungal strains. Strains used in the study (Table 1) were stored cryogenically at $-175^{\circ} \mathrm{C}$ in the Agricultural Research Service (NRRL) Culture Collection (National Center for Agricultural Utilization Research, Peoria, IL). We selected strains representing all published VCGs in F. oxysporum f. spp. asparagi (VCG 1001 to 1008) (14), dianthi (VCG 0020 to 0028 plus six additional, putatively nonpathogenic isolates from carnation; [1,6]), gladioli (VCG 0340 to 0345; [44] E. Roebroeck, unpublished data), lilii (VCG 0190 plus seven additional, putatively nonpathogenic isolates from lily [3]), spinaciae (current VCG 0330 to 0332; published as VCG 1 to 3 by Fiely et al. [15]), and tulipae (VCG 0230 [3]). Also included were 13 strains of $F$. oxysporum f. sp. lini $(26,28)$ and 22 strains of $F$. oxysporum f. sp. opuntiarum currently assigned to VCGs. Three strains of $F$. oxysporum f. sp. cubense and one of $F$. oxysporum f. sp. lycopersici were selected as references for FOC clades 1, 2, and 3, respectively (41).

Vegetative compatibility. VCG analysis in $F$. oxysporum $\mathrm{f}$. spp. lini and opuntiarum was carried out as previously described $(3,6)$ by generating nit 1 , nit3, and NitM mutants and pairing these on minimal medium. Strains of which the nit mutants complemented each other were placed in the same VCG. Novel strains from carnation, lily, and tulip were assigned to existing VCGs by generating nit mutants and pairing these with tester mutants of all known VCGs of F. oxysporum f. spp. dianthi, lilii, and tulipae, respectively.

Pathogenicity. Pathogenicity of strain NRRL 26442, received as $F$. oxysporum f. sp. lilii, was tested on universally susceptible lily cv. Esther with detached bulb scales placed in heavily infested soil, as described previously (3). Control plantlets were placed in uninfested soil. Experiments were terminated 8 weeks after planting, and plantlets were uprooted and evaluated for the presence of rot symptoms and suppression of adventitious root development.

DNA amplification and sequencing. Genomic DNA was prepared, as described previously (37). Polymerase chain reaction (PCR) amplification and sequencing of the mtSSU ribosomal DNA (rDNA) was performed with reagents and primers described by White et al. (52) and O'Donnell and Cigelnik (37). EF-1 $\alpha$ was amplified with primers EF-1 and EF-2, which prime within conserved exons (41). In addition to the amplification primers, one forward (EF-11) and two reverse internal sequencing primers (EF21 and EF-22) (41) were used with the fluorescent-labeled DyeDeoxy protocol on an automated sequencer (models 373 and 377; Perkin-Elmer Applied Biosystems, Foster City, CA). EF- $1 \alpha$ and mtSSU rDNA sequences of all exemplars were deposited in GenBank under Accession numbers AF008453, AF008456, AF008459, AF008468, AF246832 to AF246887, AF246889 to AF246892, AF250560 to AF250619, U34509, U34519, and U61608. The aligned sequences are available from K. O'Donnell upon request.

Phylogenetic analysis. Phylogenetic analyses were conducted with PAUP* version 4.0b1 (Sinauer Associates Inc., Sunderland, MA), on the combined data set of mtSSU rDNA and EF- $1 \alpha$ gene DNA sequences. Unweighted parsimony analyses were performed with the heuristic search option and 1,000 random addition sequences with the MULPARS function on and with tree bisectionreconnection branch swapping. The outgroup species selected for rooting the gene trees represent a putative sister group to the FOC $(37,39)$. Clade stability was assessed by 1,000 parsimony bootstrap replications and decay indices calculated with TREEROT. The Kishino-Hasegawa (K-H) likelihood test implemented in PAUP* compared various constrained and unconstrained topologies. Alternative topologies were rejected with $95 \%$ confidence when they were $>1.96$ standard deviation (SD) less likely than the most parsimonious tree (MPT).

AFLP analysis. Strains were grown in potato dextrose broth (Difco Laboratories, Detroit) at $24.5^{\circ} \mathrm{C}$ for 3 days. DNA was isolated from lyophilized mycelium with a Puregene kit (Gentra/Biozym, Landgraaf, the Netherlands) according to the instructions of the manufacturer, except that an additional protein precipitation step was performed. DNA (250 ng) was digested in a $50-\mu 1$ reaction volume with $E c o$ RI (10 units [U]) and $M s p I(10 \mathrm{U})$ for $5 \mathrm{~h}$ at $37^{\circ} \mathrm{C}$ in restriction ligation buffer $(10 \mathrm{mM}$ Tris/Hac at $\mathrm{pH} 7.5$, $10 \mathrm{mM} \mathrm{MgAc}, 50 \mathrm{mM} \mathrm{Kac}, 5 \mathrm{mM}$ dithiothreitol, and bovine serum albumin at $50 \mathrm{ng} / \mu \mathrm{l}$ ), and adapters were ligated overnight to the restriction fragments in $40 \mu \mathrm{l}$ of reaction product $(10 \mu \mathrm{l}$ for gel) at 10 to $12^{\circ} \mathrm{C}$. Final concentrations were $2.4 \mathrm{U}$ of T4 DNA ligase (Pharmacia, Uppsala, Sweden), $0.1 \mu \mathrm{M}$ EcoR1 adapter (5' CTCGTAGACTGCGTACC/CATCTGACGCATGGTTAA 5'), $1.0 \mu \mathrm{M} M s p \mathrm{I}$ adapter (5' GACGATGAGTCCTGAT/CTACTCAGGACTAGC 5'), and $0.2 \mathrm{mM}$ ATP (49). Ligation products were diluted 1:9 with MilliQ water. Nonselective amplification was performed with $5 \mu \mathrm{l}$ of diluted ligation product added to $20 \mu \mathrm{l}$ of buffer $(10 \mathrm{mM}$ Tris/ $\mathrm{HCl}$ at $\mathrm{pH} 8.3,50 \mathrm{mM} \mathrm{KCl}, 1.5 \mathrm{mM} \mathrm{MgCl}$ ) with $60 \mu \mathrm{M}$ dNTP, primers Eco00 (5' GACTGCGTACCAATTC) and $M s p 00$ (5' GATGAGTCCTGATCGG) at $5 \mathrm{ng} / \mu \mathrm{l}$, and $1 \mathrm{U}$ of Taq DNA polymerase (Boehringer GmbH, Mannheim, Germany). Reactions were performed in a PTC200 thermocycler (MJ Research, Watertown, MA) programmed as follows: $2 \mathrm{~min}$ at $94^{\circ} \mathrm{C} ; 35$ cycles of $30 \mathrm{~s}$ at $94^{\circ} \mathrm{C}, 30 \mathrm{~s}$ at $56^{\circ} \mathrm{C}$, and $90 \mathrm{~s}$ at $72^{\circ} \mathrm{C}$; and final extension of $10 \mathrm{~min}$ at $72^{\circ} \mathrm{C}$ and cooling to $4^{\circ} \mathrm{C}$. Amplicons were checked on $1.0 \%$ agarose gels and visualized with ethidium bromide and UV illumination.

Selective PCR was performed on $5 \mu$ of $20 \times$ diluted amplicons in a $20-\mu \mathrm{l}$ final reaction volume of the buffer mentioned above but with $200 \mu \mathrm{M}$ dNTP and $5 \mathrm{ng}$ of Cy5-labeled fluorescent Eco20 primer (5' GACTGCGTACCAATTCGC), and $30 \mathrm{ng}$ of Msp15 (5' 
GATGAGTCCTGATCGGCA) or $M s p 16$ (5' GATGAGTCCTGATCGGCC) primer. Reactions were performed under the following conditions: $2 \mathrm{~min}$ at $94^{\circ} \mathrm{C} ; 13$ cycles of $30 \mathrm{~s}$ at $94^{\circ} \mathrm{C}, 30 \mathrm{~s}$ at $65^{\circ} \mathrm{C}$, and $60 \mathrm{~s}$ at $72^{\circ} \mathrm{C}$ (annealing temperature was lowered by $0.7^{\circ} \mathrm{C}$ during each cycle); followed by 23 cycles of $30 \mathrm{~s}$ at $94^{\circ} \mathrm{C}, 30 \mathrm{~s}$ at $56^{\circ} \mathrm{C}$, and $60 \mathrm{~s}$ at $72^{\circ} \mathrm{C}$; and a final extension of $10 \mathrm{~min}$ at $72^{\circ} \mathrm{C}$ and cooling to $4^{\circ} \mathrm{C}$. Products were run on an ALFexpress automatic sequencer (Amersham Pharmacia Biotech, Roosendaal, the Netherlands) with a 50-bp ladder (Amersham) as a reference.

AFLP patterns were analyzed qualitatively with Imagemaster 1D software (Amersham) after manual correction for faint bands and obvious mismatches. The highly standardized procedure for generating AFLP patterns, including the ALFexpress and fluorescent instead of radioactively labeled gels, allowed identification of a total of 315 distinct and reproducible bands (185 bands with Msp15 and 130 bands with Msp16). A binary matrix was constructed for the presence or absence of these 315 bands in all 49 isolates. Phylogenetic analyses were performed on the binary matrix, as described above for the combined data set of DNA sequences. The matrix is available from R. P. Baayen upon request.

\section{RESULTS}

Two independent loci were examined, one from the nuclear (EF-1 $\alpha)$ and one from the mitochondrial (mtSSU rDNA) genome. Strains within a particular VCG had identical EF- $1 \alpha$ and $\mathrm{mtSSU}$ rDNA genotypes. Therefore, only one isolate per VCG is shown in Figure 1, 1 of 100 most parsimonious phylograms based on the combined EF- $1 \alpha$ gene and mtSSU rDNA data set rooted with sequences of two outgroup species, Fusarium spp. NRRL 25184 and NRRL 28387. The ingroup in both data sets was strongly supported by bootstrapping (100\%; Fig. 1). The earliest diverging lineage ( $82 \%$ bootstrap support) comprised two reference strains of $F$. oxysporum f. sp. cubense representing clade 1 sensu O'Donnell et al. (41), as well as a putatively nonpathogenic strain from lily. The reference for clade $2, F$. oxysporum $\mathrm{f}$. sp. cubense NRRL 25609, was nested in this clade (87\% bootstrap support) with $F$. oxysporum f. spp. lilii and spinaciae, part of f. spp. gladi$o l i$, lini, and dianthi, and two putatively nonpathogenic strains from lily. Clade 3 reference $F$. oxysporum f. sp. lycopersici NRRL 26383 fell in a third clade with $87 \%$ bootstrap support together with $F$. oxysporum f. spp. asparagi, opuntiarum, and tulipae, part of f. sp. gladioli, and putatively nonpathogenic strains from lily and carnation. The remaining strains fell in three small lineages that were unresolved with respect to clades 2 and 3 (Fig. 1) but were nested in clade 2 in a phylogram derived from a subset of strains (bootstrap support 62\%; Fig. 2B).

A subset of strains was selected to cover most of the genetic diversity indicated by the sequence data and was analyzed by AFLP. Parsimony analysis of these AFLP data yielded a phylogram that resolved many of the clades from the sequence-based phylogram. Although clade stability was distinctly less, the close concordance of sequence and AFLP-based trees was striking (Fig. 2A and B). With a consistency index of 0.43 , the AFLP-based tree (Fig. 2A) was considerably more homoplasious than the sequence-based tree (Fig. 2B), that had a consistency index of 0.97 . The number of nodes with high bootstrap values (13 nodes $\geq 90 \% ; 22$ nodes $\geq$ $70 \%$ ) was higher in the AFLP-based tree than in the sequencebased tree ( 7 nodes $\geq 90 \%$ and 12 nodes $\geq 70 \%$ ) (Table 2 ). Moreover, 12 nodes in the AFLP tree with $\geq 90 \%$ bootstrap support corresponded to strains with identical genotypes in the sequencebased tree (Fig. 2).

F. oxysporum f. sp. lilii (NRRL 28395 and 26955) VCG 0190 was resolved as a distinct lineage in clade 2 in the AFLP and DNA sequence-based phylograms. Except for NRRL 26442, all putatively nonpathogenic strains tested from lily proved unrelated to VCG 0190 (Fig. 1). Strain NRRL 26442 was received as $F$. oxysporum f. sp. lilii but proved nonpathogenic to universally susceptible lily cv. Esther and formed a single-member VCG distinct from VCG 0190 (Fig. 1). The identity of NRRL 26442, thus, remains unresolved. While $F$. oxysporum f. sp. lilii belonged to clade 2, two formae speciales ( $F$. oxysporum f. spp. tulipae and asparagi) pathogenic to related liliaceous genera were nested within clade 3. F. oxysporum f. sp. tulipae NRRL 26954 (VCG 0230) was close to $F$. oxysporum f. sp. asparagi NRRL 28372 (VCG 1006) both in the AFLP phylogram and in the gene genealogies (Fig. 2A and B). A close relationship was observed for VCGs 1001, 1003, 1004, 1005, and 1007 of F. oxysporum f. sp. asparagi (Figs. 1 and 2); the remaining three VCGs of this forma specialis belonged to different lineages in clade 3 sensu O'Donnell et al. (41).

Five distinct lineages were identified in F. oxysporum f. sp. gladioli among six VCGs from iridaceous genera. Three VCGs (0341, 0342, and 0343) were nested in clade 2 (Fig. 2B) and three in clade 3 (0340, 0344, and 0345). Self-incompatible NRRL 28918 , the type strain of $F$. oxysporum f. sp. gladioli originally studied by Massey (31), appeared to be more closely related to VCG 0343 NRRL 26993 (Fig. 1) than to the presently common VCG 0340. A schematic representation of phylogenetic lineages, VCGs, and host specificity (races) in F. oxysporum f. sp. gladioli is given in Table 3.

Both AFLP and sequence data identified a close relationship between $F$. oxysporum f. sp. gladioli NRRL 28406, VCG 0341, and $F$. oxysporum f. sp. dianthi NRRL 28401, VCG 0021, rather than a relationship of either VCG with other VCGs in the two respective formae speciales (Fig. 2). VCG 0021 harbored the dominant, cosmopolitan race 2 of $F$. oxysporum f. sp. dianthi. The remaining five VCGs (0020, 0022, 0025, 0027, and 0028) belonged to clade 2 . Resolution in clade 2 was relatively poor using both methods (Fig. 2), leaving phylogenetic relationships within $F$. oxysporum f. sp. dianthi partially unresolved. In contrast, putatively nonpathogenic strains from carnation, including members of a large carnation-associated VCG with potential for biological control of Fusarium wilt represented by NRRL 26994 and NRRL $28376(1,43)$, were all nested in clade 3 , thereby excluding a close relationship to strains of $F$. oxysporum $\mathrm{f}$. sp. dianthi. An overview of phylogenetic lineages, VCGs, pathogenicity, and cultivar specificity (races) is given in Table 4.

Attempts to identify VCGs among isolates of $F$. oxysporum $\mathrm{f}$. sp. lini were largely unsuccessful. Apart from two compatible strains from Russia (NRRL 29084 and NRRL 29094), all strains of $F$. oxysporum f. sp. lini were either self-incompatible or proved to have a nit-mutant rather than wild-type phenotype from the start. Despite the availability of mutants from all strains, including several NitM mutants, no complementation reactions were observed. Of the four $F$. oxysporum f. sp. lini-containing lineages that received strong bootstrap support (99 to 100\%) in the AFLP phylogram, two coincided with strongly supported $F$. oxysporum $\mathrm{f}$. sp. lini clades in the sequence-based phylogram (Fig. 2A). Among the f. sp. lini lineages, two were found exclusively in Russia (NRRL 29084 and 29094) and Argentina (NRRL 28919 and 28920) (Table 5). The three VCGs in F. oxysporum f. sp. spinaciae (VCGs 0330 to 0332 , corresponding to VCG 1 to 3 of Fiely et al. [15]) formed a monophyletic lineage in clade 2 with VCG 0342 of F. oxysporum f. sp. gladioli.

VCG diversity was high among isolates from Cactaceae (Table 1). Six isolates were vegetatively incompatible with all others. Only two isolates from different hosts (NRRL 28391 from Dolichotele sp. and NRRL 29274 from Cereus sp.) belonged to the same VCG (0455); those in VCG 0450 were recovered from two cactus genera, Rhipsalidopsis and Schlumbergera, from the same commercial greenhouse. Isolates NRRL 28368 from Disco sp. and NRRL 28391 from Dolichotele sp. were vegetatively incompatible but had virtually identical AFLP profiles (Fig. 2) and formed a well-supported ( $96 \%$ bootstrap interval) lineage in the gene genealogy (Fig. 1). 
F. oxysporum f. sp. opuntiarum, with the exception of NRRL 28169 , appeared to be monophyletic. Results of a K-H analysis of F. oxysporum f. sp. opuntiarum monophyly constraint strongly support $(P=0.8023$; Table 6$)$ the exclusive origin of this forma specialis. Constraints that forced the monophyly of $F$. oxysporum f. spp. asparagi, dianthi, gladioli, and lini were significantly worse than the MPT (Table 6).

\section{DISCUSSION}

In contrast to what is generally assumed, formae speciales in the FOC are frequently nonmonophyletic. Evidence for a paraphyletic or polyphyletic origin was presented for the first time by O'Donnell et al. (41) for $F$. oxysporum f. sp. cubense. Their results were supported by cluster analysis of DNA amplification finger-

TABLE 1. Strains of the Fusarium oxysporum complex and outgroups sequenced in this study

\begin{tabular}{|c|c|c|c|c|c|}
\hline Taxon, $\mathrm{VCG},{ }^{\mathrm{a}}$ and race & Host/substrate & Origin & $\mathrm{NRRL}^{\mathrm{b}}$ & Source $^{c}$ & AFLP $^{d}$ \\
\hline \multicolumn{6}{|c|}{ F. oxysporum f. sp. asparagi } \\
\hline VCG 1001 & Asparagus officinalis & United States & 28973 & FGSC 6608 & + \\
\hline VCG 1002 & Asparagus officinalis & United States & 28362 & FGSC 6609 & + \\
\hline VCG 1003 & Asparagus officinalis & United States & 28404 & FGSC 6611 & + \\
\hline VCG 1004 & Asparagus officinalis & United States & 28378 & FGSC 6613 & + \\
\hline VCG 1005 & Asparagus officinalis & United States & 28398 & FGSC 6615 & + \\
\hline VCG 1006 & Asparagus officinalis & United States & 28372 & FGSC 6617 & + \\
\hline VCG 1007 & Asparagus officinalis & United States & 28384 & FGSC 6619 & + \\
\hline VCG 1008 & Asparagus officinalis & United States & 28379 & FGSC 6621 & + \\
\hline \multicolumn{6}{|c|}{ F. oxysporum f. sp. cubense } \\
\hline VCG 0120 & Musa sp. & Australia & $25603^{\text {clade } 1}$ & Kistler A2 & - \\
\hline VCG 01210 & Musa sp. & United States & $26029^{\text {clade } 1}$ & Kistler A15 & - \\
\hline VCG 01214 & Musa sp. & Malawi & $25609^{\text {clade } 2}$ & Kistler MW2 & + \\
\hline \multicolumn{6}{|c|}{ F. oxysporum f. sp. dianthi } \\
\hline VCG 0020, race 4 & Dianthus caryophyllus & United States & 26147 & IMI 141130 & + \\
\hline VCG 0020, race 4 & Dianthus caryophyllus & Italy & 26965 & Garibaldi F140 & + \\
\hline VCG 0020, race 4 & Dianthus caryophyllus & Italy & 28902 & Garibaldi F310 & + \\
\hline VCG 0020, race 4 & Dianthus caryophyllus & Italy & 28903 & Garibaldi F79 & + \\
\hline VCG 0020, race 4 & Dianthus caryophyllus & Italy & 28904 & Garibaldi F261 & + \\
\hline VCG 0020 , race 4 & Dianthus caryophyllus & Italy & 28905 & Garibaldi F828 & + \\
\hline VCG 0021 , race 2 & Dianthus caryophyllus & Israel & 26222 & CBS 416.90 & - \\
\hline VCG 0021 , race 2 & Dianthus caryophyllus & The Netherlands & 28401 & IPO WCS816 & + \\
\hline VCG 0021 , race 2 & Dianthus caryophyllus & Italy & 28403 & Garibaldi F107 & - \\
\hline VCG 0022 , race 1 & Dianthus caryophyllus & Italy & 26964 & Garibaldi F100 & + \\
\hline VCG 0022 , race 1 & Dianthus caryophyllus & Italy & 28389 & Garibaldi F521 & + \\
\hline VCG 0022 , race 8 & Dianthus caryophyllus & Italy & 28356 & Garibaldi F639 & + \\
\hline VCG 0022 , race 8 & Dianthus caryophyllus & Italy & 28399 & Garibaldi F773 & + \\
\hline VCG 0025 , race 11 & Dianthus caryophyllus & The Netherlands & 26960 & PD 90/291 & + \\
\hline VCG 0027, race 10 & Dianthus caryophyllus & The Netherlands & 26962 & IPO WCS842 & + \\
\hline VCG 0027, race 10 & Dianthus caryophyllus & The Netherlands & 28365 & IPO NAKS3 & - \\
\hline VCG 0028, race 9 & Dianthus caryophyllus & Australia & 26961 & Kalc Wright 70 & + \\
\hline VCG 0028, race 9 & Dianthus caryophyllus & Australia & 28377 & Kalc Wright 68 & - \\
\hline VCG 0028, race 9 & Dianthus caryophyllus & Australia & 28906 & Kalc Wright B6D214/2 & - \\
\hline VCG 0028, race 9 & Dianthus caryophyllus & Australia & 28907 & Kalc Wright B9D221/2 & - \\
\hline \multicolumn{6}{|c|}{ F. oxysporum f. sp. gladioli } \\
\hline VCG 0340 , race 1 & Gladiolus $\times$ grandiflorus & France & 26992 & LBO G2 & + \\
\hline VCG 0340, race 1 & Gladiolus italicus & The Netherlands & 28394 & LBO G15 & - \\
\hline VCG 0340 , race $2 n$ & Gladiolus $\times$ nanus & The Netherlands & 28911 & LBO G6 & - \\
\hline VCG 0340 , race $2 n$ & Ixia sp. & The Netherlands & 28912 & LBO X1 & - \\
\hline VCG 0340 , race $2 \mathrm{i}$ & Iris $\times$ hollandica & The Netherlands & 28385 & LBO Ir2 & - \\
\hline VCG 0340 , race $2 \mathrm{i}$ & Iris $\times$ hollandica & The Netherlands & 28913 & LBO Ir1 & - \\
\hline VCG 0340 , race 3 & Crocus sp. & The Netherlands & 28914 & $\mathrm{LBO} \mathrm{Cr} 7$ & - \\
\hline VCG 0340 , race 3 & Crocus sp. & The Netherlands & 28915 & LBO Cr12 & - \\
\hline VCG 0340, race 4 & Crocus sp. & The Netherlands & 28916 & LBO Cr4 & - \\
\hline VCG 0340 , race 4 & Crocus sp. & The Netherlands & 28917 & LBO Cr8 & - \\
\hline VCG 0341 , race 5 & Freesia sp. & The Netherlands & 26988 & LBO Fr10 & - \\
\hline VCG 0341 , race 5 & Gladiolus $\times$ colvillei & The Netherlands & 28406 & LBO G23 & + \\
\hline VCG 0342 , race $2 \mathrm{c}$ & Crocus sp. & The Netherlands & 26991 & LBO Cr1 & + \\
\hline VCG 0342 , race $2 \mathrm{c}$ & Crocus sp. & Unknown & 28388 & $\mathrm{LBO} \mathrm{Cr} 2$ & - \\
\hline VCG 0343 , race 1 it & Gladiolus $\times$ grandiflorus & Italy & 26993 & LBO G82 & + \\
\hline VCG 0343 , race 1 it & Gladiolus $\times$ grandiflorus & Italy & 28360 & LBO G76 & - \\
\hline VCG 0344 , new race & Freesia sp. & The Netherlands & 26989 & LBO Fr11 & + \\
\hline VCG 0345 , new race & Freesia sp. & The Netherlands & 26990 & LBO Fr12 & + \\
\hline VCG 034-si & Gladiolus sp. & United States & 28918 & CBS 151.27 & - \\
\hline \multicolumn{6}{|l|}{ F. oxysporum f. sp. lilii } \\
\hline VCG 0190 & Lilium sp. & The Netherlands & 26955 & CPRO Fol4 & + \\
\hline
\end{tabular}

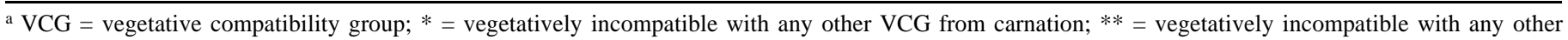
VCG from lily; *** = vegetative compatibility tested but not sequenced.

b Reference strains for clades 1, 2, and 3 of O'Donnell et al. (41) in superscript.

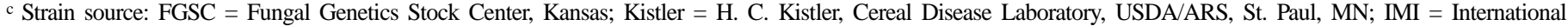
Mycological Institute (CABI Bioscience), Egham, U.K.; Garibaldi = A. Garibaldi, Turin University, Turin, Italy;. CBS = Centraalbureau voor Schimmelcultures, Baarn, the Netherlands; IPO = Research Institute for Plant Protection, Wageningen, the Netherlands; Kalc Wright = G. F. Kalc Wright, Parkville, Australia; LBO = Bulb Research Centre, Lisse, the Netherlands; CPRO = Centre for Plant Breeding and Reproduction Research, Wageningen, the Netherlands; PD = Plantenziektenkundige Dienst, Wageningen, the Netherlands; DAOM = Department of Agriculture (Mycology) and Agri-Food, Ottawa, Canada; BBA = Biologische Bundesanstalt für Landund Forstwirtschaft, Berlin; Fiely = M. B. Fiely, University of Arkansas, Fayetteville; BCRI = British Columbia Research Inc., Vancouver, Canada.

${ }^{\mathrm{d}} \mathrm{AFLP}=$ amplified fragment length polymorphism. Strains subjected (+) and not subjected (-) to AFLP analysis. 
prints (7). The present study provides evidence for multiple evolutionary origins of $F$. oxysporum f. spp. asparagi, dianthi, gladioli, and lini. A phylogram inferred from the AFLP data set was strikingly similar to one inferred from combined EF- $1 \alpha$ and mtSSU rDNA sequences. Both approaches complement each other: AFLP analysis, in theory, samples loci throughout the entire genome, while gene genealogies examine the evolution of nuclear and mitochondrial gene sequences. Clades that are supported by AFLP and gene genealogies are likely to reflect independent measures of the evolutionary history of these fungi. The con-

TABLE 1. (continued from preceding page)

\begin{tabular}{|c|c|c|c|c|c|}
\hline Taxon, $\mathrm{VCG}^{\mathrm{a}}$, and race & Host/substrate & Origin & $\mathrm{NRRL}^{\mathrm{b}}$ & Source $^{c}$ & AFLPd $^{d}$ \\
\hline VCG 0190 & Lilium sp. & Italy & 28395 & CPRO Fol28 & + \\
\hline VCG 0190 & Lilium sp. & Poland & 28908 & CPRO Fol80 & - \\
\hline \multicolumn{6}{|l|}{ F. oxysporum f. sp. lini } \\
\hline VCG 0440 & Linum usitatissimum & Russia & 29084 & CPRO U2 & + \\
\hline VCG 0440 & Linum usitatissimum & Russia & 29094 & CPRO U1 & + \\
\hline VCG 044- & Linum usitatissimum & Argentina & 28919 & CPRO A1 & + \\
\hline VCG 044- & Linum usitatissimum & Argentina & 28920 & CPRO A2 & + \\
\hline VCG 044- & Linum usitatissimum & Belgium & 28921 & CPRO B1 & + \\
\hline VCG 044- & Linum usitatissimum & Belgium & 28922 & CPRO B2 & + \\
\hline VCG 044- & Linum usitatissimum & Canada & 28923 & CPRO C1 & + \\
\hline VCG 044- & Linum usitatissimum & Canada & 28924 & CPRO C2 & + \\
\hline VCG 044- & Linum usitatissimum & France & 28925 & CPRO F1 & + \\
\hline VCG 044- & Linum usitatissimum & France & 28926 & CPRO F26 & + \\
\hline VCG 044- & Linum usitatissimum & The Netherlands & 28928 & CPRO N1 & + \\
\hline VCG 044- & Linum usitatissimum & The Netherlands & 28929 & CPRO N3 & + \\
\hline VCG 044- & Linum usitatissimum & The Netherlands & 28930 & CPRO N10 & + \\
\hline \multicolumn{6}{|c|}{ F. oxysporum f. sp. lycopersici } \\
\hline VCG unknown & Lycopersicon esculentum & & $26383^{\text {clade } 3}$ & & + \\
\hline \multicolumn{6}{|c|}{ F. oxysporum f. sp. opuntiarum } \\
\hline VCG 0450 & Rhipsalidopsis sp. & The Netherlands & 28363 & IPO 96-11 & + \\
\hline VCG 0450 & Rhipsalidopsis sp. & The Netherlands & 28367 & IPO 96-15 & + \\
\hline VCG 0450 & Rhipsalidopsis sp. & The Netherlands & 28370 & IPO 96-18 & - \\
\hline VCG 0450 & Schlumbergera $\mathrm{sp}$. & The Netherlands & 28402 & IPO 96-32 & - \\
\hline VCG 0450 & Rhipsalidopsis sp. & The Netherlands & 28405 & IPO 96-21 & - \\
\hline VCG 0450 & Rhipsalidopsis sp. & The Netherlands & 28933 & IPO 96-13 & - \\
\hline VCG 0450 & Rhipsalidopsis sp. & The Netherlands & 28934 & IPO 96-14 & - \\
\hline VCG 0450 & Rhipsalidopsis sp. & The Netherlands & 28937 & IPO 96-23 & - \\
\hline VCG 0450 & Rhipsalidopsis sp. & The Netherlands & 28938 & IPO 96-24 & - \\
\hline VCG 0450 & Schlumbergera sp. & The Netherlands & 28939 & IPO 96-33 & - \\
\hline VCG 0450 & Schlumbergera sp. & The Netherlands & 28940 & IPO 96-34 & - \\
\hline VCG 0450 & Schlumbergera sp. & The Netherlands & 28941 & IPO 96-36 & - \\
\hline VCG 0450 & Rhipsalidopsis sp. & The Netherlands & 29126 & IPO 96-16NitM & - \\
\hline VCG 0450 & Rhipsalidopsis sp. & The Netherlands & 29127 & IPO 96-17nit3 & - \\
\hline VCG 0451 & Disco placentiformis & The Netherlands & 28368 & PD 94/123 & + \\
\hline VCG 0452 & Cactus & Canada & 28169 & DAOM 215628 & - \\
\hline VCG 0453 & Zygocactus sp. & Germany & 28243 & BBA 64709 & - \\
\hline VCG 0454 & Ferocactus sp. & Germany & 28279 & BBA 62346 & + \\
\hline VCG 0455 & Dolichotele sp. & The Netherlands & 28391 & PD 95/1408 & + \\
\hline VCG 0455 & Cereus sp. & The Netherlands & $29274 * * *$ & PD $99 / 3057$ & - \\
\hline VCG 0456 & Opuntia microdasys & The Netherlands & $29272 * * *$ & PD $99 / 6057$ & - \\
\hline VCG $045-$ & Zygocactus sp. & Germany & 22548 & BBA 62349 & - \\
\hline \multicolumn{6}{|c|}{ F. oxysporum f. sp. spinaciae } \\
\hline VCG 0330 & Spinacea oleracea & United States & 26874 & Fiely MF 15 & - \\
\hline VCG 0331 & Spinacea oleracea & United States & 26875 & Fiely MF 34 & - \\
\hline VCG 0332 & Spinacea oleracea & United States & 26876 & Fiely MF 42 & - \\
\hline \multicolumn{6}{|l|}{ F. oxysporum f. sp. tulipae } \\
\hline VCG 0230 & Tulipa $\times$ gesneriana & Germany & 22556 & CBS 242.59; BBA 8248 & - \\
\hline VCG 0230 & Tulipa $\times$ gesneriana & The Netherlands & 26954 & LBO Tu10 & + \\
\hline VCG 0230 & Tulipa $\times$ gesneriana & The Netherlands & 28974 & LBO Tu4 & + \\
\hline \multicolumn{6}{|c|}{ F. oxysporum, putatively nonpathogenic } \\
\hline VCG 1 & Dianthus caryophyllus & The Netherlands & 26994 & PD $89 / 1523$ & + \\
\hline VCG 1 & Dianthus caryophyllus & Israel & 28376 & Manicom X40 & - \\
\hline Unique $\mathrm{VCG}^{*}$ & Dianthus caryophyllus & The Netherlands & 28369 & PD 90/1580.2 & - \\
\hline Unique $\mathrm{VCG}^{*}$ & Dianthus caryophyllus & The Netherlands & 28392 & PD $90 / 1580.1$ & - \\
\hline Unique $\mathrm{VCG}^{*}$ & Dianthus caryophyllus & The Netherlands & 28380 & PD 90/440 & - \\
\hline Unique $\mathrm{VCG}^{*}$ & Dianthus caryophyllus & Israel & 28396 & Manicom X48 & - \\
\hline Unique $\mathrm{VCG}^{* *}$ & Lilium sp. & United States & 26442 & IMI 141108 & - \\
\hline Unique $\mathrm{VCG} * *$ & Lilium sp. & The Netherlands & 28358 & CPRO Fol17 & - \\
\hline Unique $\mathrm{VCG}^{* *}$ & Lilium sp. & The Netherlands & 28359 & CPRO Fol14 & - \\
\hline Unique $\mathrm{VCG}^{* * *}$ & Lilium sp. & Italy & 28361 & CPRO Fol77 & + \\
\hline Unique $\mathrm{VCG}^{* * *}$ & Lilium sp. & United States & 28366 & CPRO Fol67 & + \\
\hline Unique VCG** & Lilium sp. & United States & 28371 & CPRO Fol65 & + \\
\hline Unique $\mathrm{VCG}^{* *}$ & Lilium sp. & The Netherlands & 28397 & CPRO Fol6 & + \\
\hline \multicolumn{6}{|l|}{ Fusarium } \\
\hline VCG not tested & Pseudotsuga menziesii & United States & 22903 & BCRI 3139 & - \\
\hline VCG not tested & Dianthus caryophyllus & The Netherlands & 28387 & PD $90 / 1377$ & + \\
\hline \multicolumn{6}{|l|}{ Fusarium } \\
\hline VCG not tested & Peat soil & Germany & 25184 & BBA 65467 & - \\
\hline
\end{tabular}


sistency index was considerably lower with the AFLP-based phylogeny. This is in accord with a recent phylogenetic analysis of RAPD data for seven FOC isolates from maize and three outgroup strains, which revealed the same underlying phylogeny as EF-1 $\alpha$ and mtSSU rDNA gene genealogies but with a much higher level of homoplasy than sequence data (40). Recent phylogenetic analysis of exclusively RAPD data from strains from cucurbitaceous hosts also supports the nonmonophyletic nature

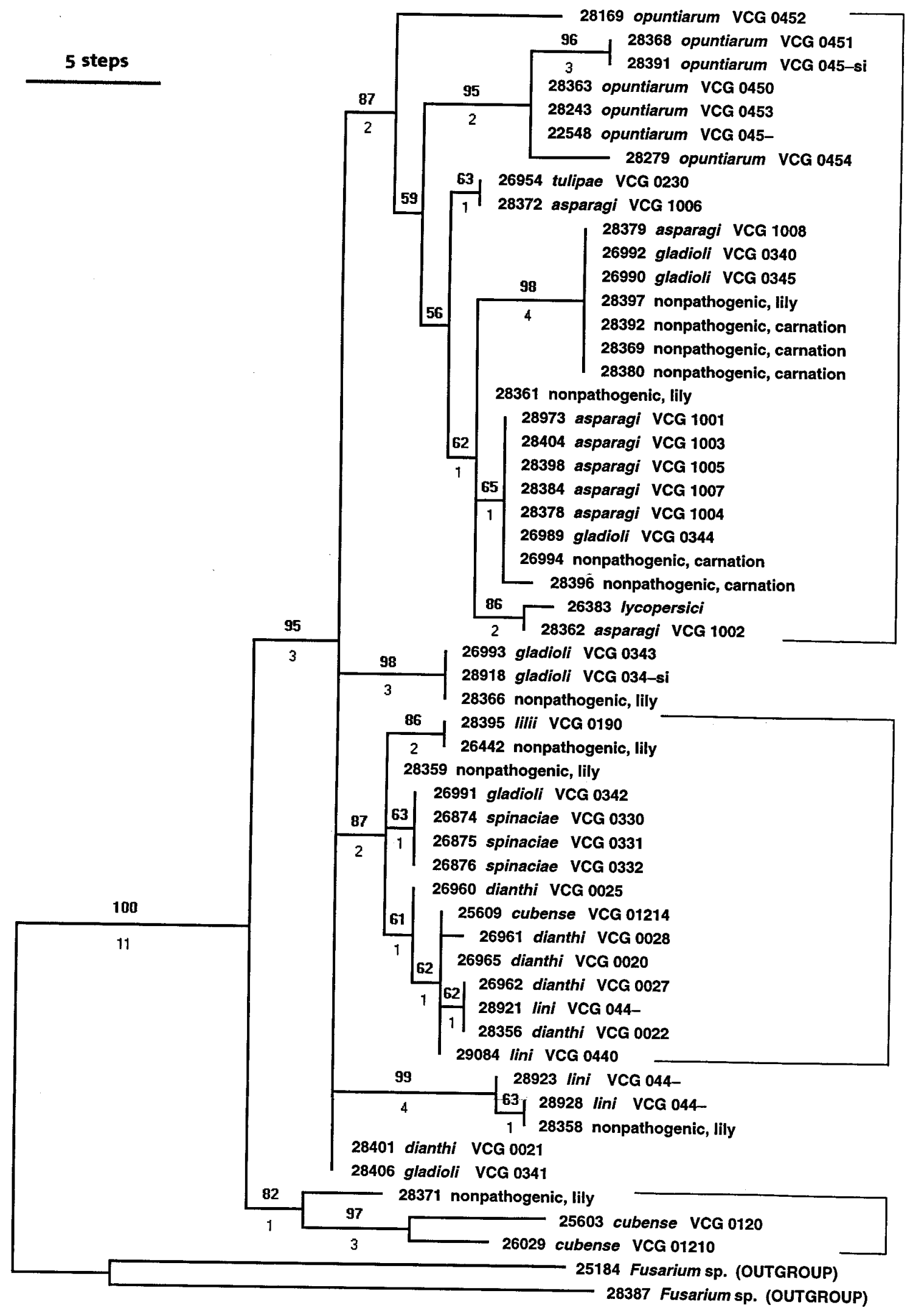

Clade 3

Clade 2

Clade 1

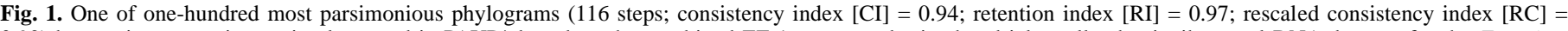

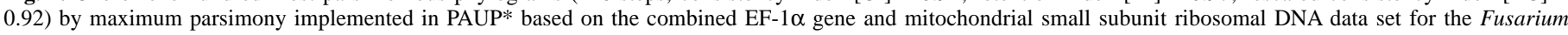

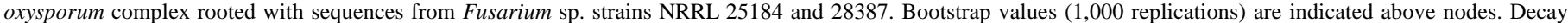
indices calculated with TREEROT are indicated below nodes. Only one strain is shown per vegetative compatibility group (VCG) and genotype. 
of some formae speciales (cucumerinum and niveum), while others appear to be monophyletic (radicis-cucumerinum and melonis) (48). In the latter study, cross-compatibility between nit mutants from strains of $F$. oxysporum f. sp. radicis-cucumerinum VCGs
0260 and 0261 , which have the same RAPD pattern, indicates that this forma specialis may represent a single recently diverged clonal lineage. Similar results have been reported for VCGs 0030 and 0032 of F. oxysporum f. sp. lycopersici (34).

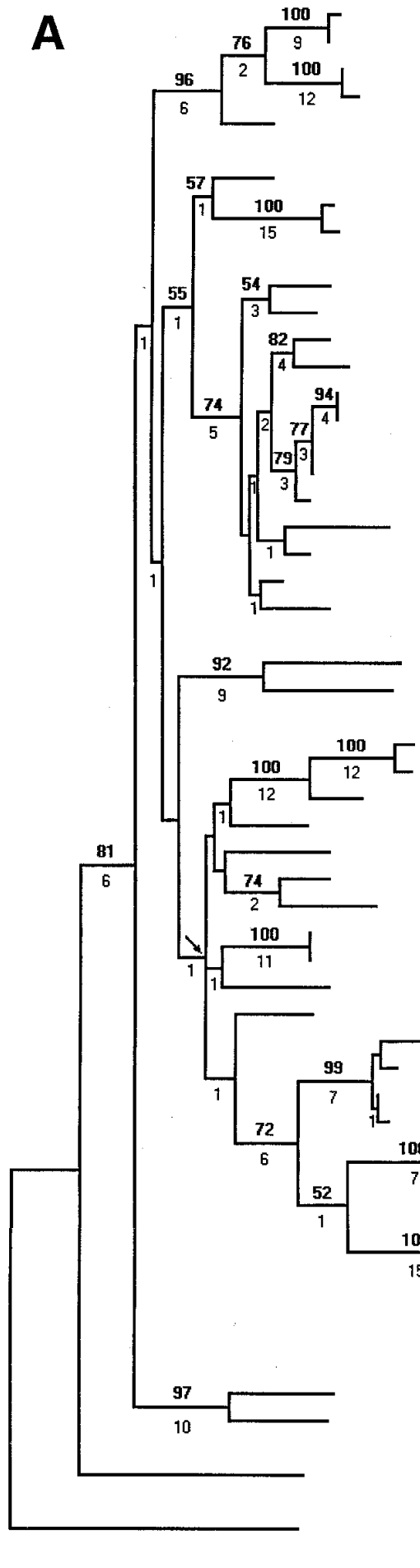

25 steps
28368 opuntiarum 28391 opuntiarum 28363 opuntiarum 28367 opuntiarum 28279 opuntiarum

28372 asparagi 28974 tulipae 26954 tulipae

28379 asparagi

26992 gladioli

26990 gladioli

28397 nonpathogenic

28973 asparagi

28404 asparagi

28398 asparagi

28384 asparagi

28378 asparagi

26383 lycopersici $\quad$ gladioli 26989

28362 asparagi nonpathogenic 26994 26989 gladioli lycopersici 26383 26994 nonpathogenic asparagi 28362

26993 gladioli

28366 nonpathogenic

26955 lili

28395 Iilii

26991 gladioli

25609 cubense dianthi 26960

26960 dianthi cubense 25609

26961 dianthi

26962 dianthi dianthi 26965

28919 lini

28920 lini

26965 dianthi

28356 dianthi

28924 lini

28929 lini

28930 lini

28921 lini

29094 lini

29084 lini

$28923 \mathrm{lin} I$

28928 lini

28922 lini

28926 lini

28925 lini

28401 dianthi

28406 gladioli

28371 nonpathogenic

28387 Fusarium sp.

(OUTGROUP)

lanthi 26962

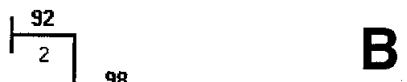

\section{Clade 3}
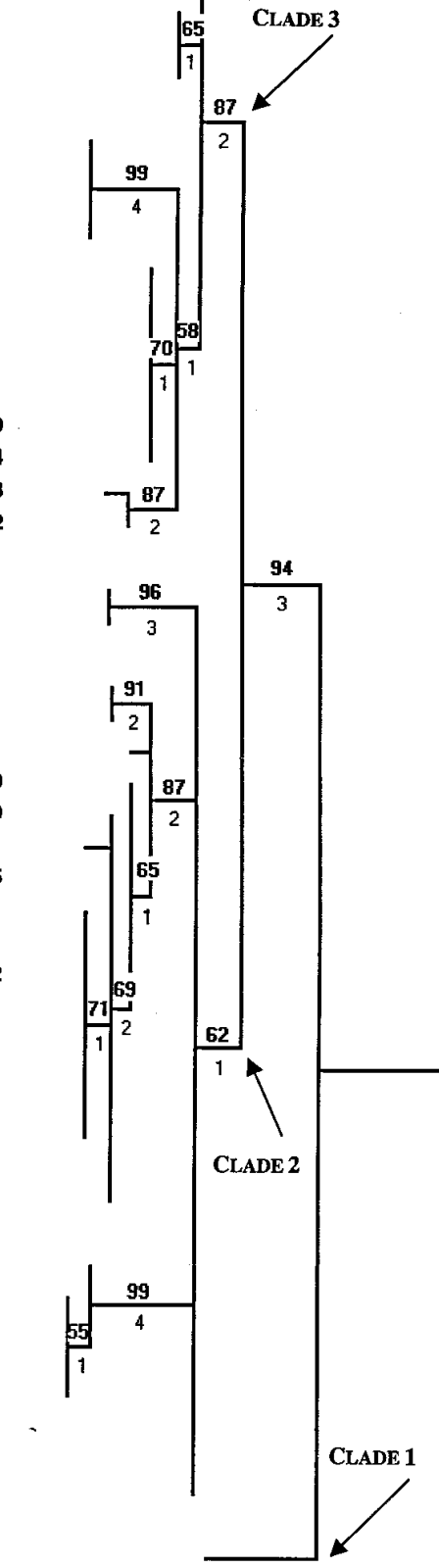

ADE 1

10 steps

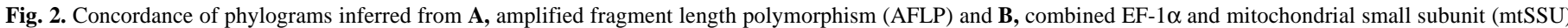

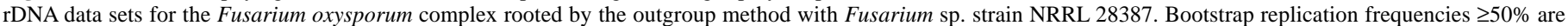

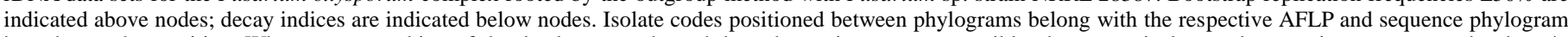

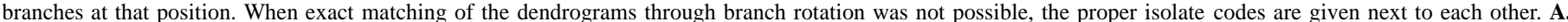

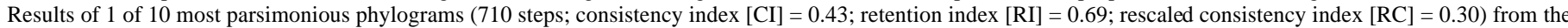

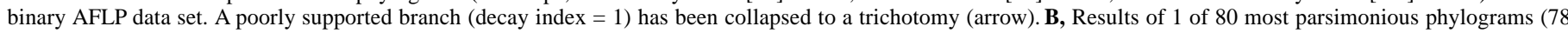

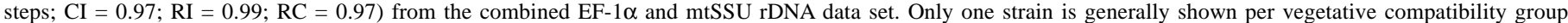
(VCG), because AFLP fingerprints and sequence genotypes were virtually identical within VCGs. 
TABLE 2. Comparison of amplified fragment length polymorphism (AFLP) and gene sequence tree statistics

\begin{tabular}{lccccccc}
\hline Analysis & Characters & $\begin{array}{c}\text { Parsimony } \\
\text { tree length }\end{array}$ & Trees & $\begin{array}{c}\text { Consistency } \\
\text { index }\end{array}$ & $\begin{array}{c}\text { Autapomorphies/ } \\
\text { synapomorphies }\end{array}$ & $\begin{array}{c}\text { Nodes } \geq 70 \% \\
\text { bootstrap }\end{array}$ & $\begin{array}{c}\text { Nodes } \geq 90 \% \\
\text { bootstrap }\end{array}$ \\
\hline AFLP & 315 & 710 & 10 & 0.43 & $100 / 205$ & 22 & 13 \\
mtSSU rDNA + EF-1 $\alpha$ & 1,396 & 78 & 80 & 0.97 & $39 / 40$ & 12 & 7 \\
\hline
\end{tabular}

${ }^{\mathrm{a}}$ Shown in Figure 2.

${ }^{\mathrm{b}} \mathrm{mtSSU}=$ mitochondrial small subunit.

TABLE 3. Relation of EF-1 $\alpha$ and mitochondrial small subunit (mtSSU) ribosomal DNA genotypes in Fusarium oxysporum f. sp. gladioli with the known vegetative compatibility group (VCG), amplified fragment length polymorphism (AFLP)/restriction fragment length polymorphism (RFLP) and race structure

\begin{tabular}{lcccc}
\hline Genotype & $\begin{array}{c}\text { Representative } \\
\text { strain }\end{array}$ & VCG & $\begin{array}{c}\text { AFLP/RFLP } \\
\text { group }\end{array}$ & Race \\
\hline 1 & NRRL 28406 & 0341 & II & 5 \\
2 & NRRL 26991 & 0342 & III & 2c \\
3 & NRRL 26993 & 0343 & V & 1it \\
& NRRL 28918 & $034-$ & IV & Unknown \\
4 & NRRL 26992 & 0340 & I & 1 \\
& NRRL 28911 & 0340 & I & 2 n \\
& NRRL 28385 & 0340 & Ib & $2 \mathrm{i}$ \\
& NRRL 28914 & 0340 & Ic & 3 \\
& NRRL 28916 & 0340 & Id & 4 \\
& NRRL 26990 & 0345 & XXI & Unknown \\
5 & NRRL 26989 & 0344 & XX & Unknown \\
\hline
\end{tabular}

${ }^{a}$ Mes et al. $(33,44)$; E. J. A. Roebroeck, unpublished data.

TABLE 4. Relation of EF-1 $\alpha$ and mitochondrial small subunit (mtSSU) rDNA genotypes in Fusarium oxysporum f. sp. dianthi with known vegetative compatibility group (VCG), restriction fragment length polymorphism (RFLP), esterase, and race structure

\begin{tabular}{lcccc}
\hline Genotype & $\begin{array}{c}\text { Representative } \\
\text { strain }\end{array}$ & VCG & $\begin{array}{c}\text { RFLP/esterase } \\
\text { group }\end{array}$ & Race \\
\hline 1 & NRRL 28401 & 0021 & II & 2 \\
2 & NRRL 26964 & 0022 & III & 1 \\
& NRRL 28356 & 0022 & III & 8 \\
& NRRL 26962 & 0027 & V & 10 \\
3 & NRRL 26965 & 0020 & I & 4 \\
4 & NRRL 26961 & 0028 & VI & 9 \\
5 & NRRL 26960 & 0025 & IV & 11 \\
\hline
\end{tabular}

a Aloi and Baayen (1) and Baayen et al. (6).

Formae speciales harboring a single VCG, such as $F$. oxysporum f. spp. lilii and tulipae, are generally assumed to be clonal (3). However, VCGs within given formae speciales may or may not form exclusive groups in the molecular phylogeny. For example, the five VCGs in $F$. oxysporum $\mathrm{f}$. sp. asparagi (VCGs $1001,1003,1004,1005$, and 1007) form a monophyletic group, as do VCGs 0340 and 0345 of $F$. oxysporum f. sp. gladioli. In addition, all three VCGs of $F$. oxysporum f. sp. spinaciae (15) form an exclusive group in the gene tree, indicating that this forma specialis is monophyletic. Although F. oxysporum f. sp. opuntiarum appears to represent a paraphyletic grade, results of a K-H analysis support a possible monophyletic origin. All of the other formae speciales studied have paraphyletic or polyphyletic origins, with F. oxysporum f. sp. gladioli being the most diverse in evolution.

Phylograms based on EF- $1 \alpha$ and mtSSU rDNA sequences resolved five distinct lineages in F. oxysporum f. sp. gladioli. Races within VCG 0340, left unresolved in the gene genealogies, have recently been resolved with high-resolution AFLP analyses (E. Roebroeck, unpublished data). In general, AFLP analyses have a higher resolution at a refined level, while analysis of the EF-1 $\alpha$
TABLE 5. Relation of EF-1 $\alpha$ and mitochondrial small subunit (mtSSU) rDNA genotypes in Fusarium oxysporum f. sp. lini with vegetative compatibility group (VCG) and amplified fragment length polymorphism (AFLP) structure ${ }^{a}$

\begin{tabular}{|c|c|c|c|c|}
\hline Genotype & $\begin{array}{c}\text { Representative } \\
\text { strain }\end{array}$ & VCG & $\begin{array}{l}\text { AFLP } \\
\text { group }\end{array}$ & Geographic origin \\
\hline $1 \mathrm{a}$ & NRRL 28928 & 044- & $1 \mathrm{a}$ & $\begin{array}{l}\text { The Netherlands, Belgium, } \\
\text { France }\end{array}$ \\
\hline $1 b$ & NRRL 28923 & 044- & $1 b$ & Canada \\
\hline 2 & NRRL 29084 & 0440 & 2 & Russia \\
\hline \multirow[t]{2}{*}{3} & NRRL 28921 & $044-$ & 3 & $\begin{array}{l}\text { The Netherlands, Belgium, } \\
\text { Canada }\end{array}$ \\
\hline & NRRL 28919 & $044-$ & 4 & Argentina \\
\hline
\end{tabular}

${ }^{a}$ Kroes (26) and Kroes et al. (28).

and mtSSU rDNA gene sequence resolves higher order phylogenies. Phylogenetic analysis of the rDNA internal transcribed spacer (ITS) region, while useful in many organisms, is cladistically uninformative in the G. fujikuroi and $F$. oxysporum species complexes and misleading due to the presence of two nonorthologous intragenomic rDNA ITS2 types within all known species $(37,39,50,51)$.

Rot-associated formae speciales have often been considered less specialized and phylogenetically distinct from xylem vesselcolonizing pathogens. However, our results show that rot- and wilt-associated VCGs are equally dispersed throughout the molecular phylogeny. At present, clearcut distinctions in pathology between both groups are unavailable. F. oxysporum f. spp. lilii and tulipae are cortex colonizers (5). F. oxysporum f. sp. gladioli colonizes both the cortex and xylem (10). F. oxysporum f. sp. opuntiarum causes root and stem rot of Cactaceae rather than invading the xylem (18). F. oxysporum f. spp. lini and basilici induce both a typical root-rot syndrome as well as a wilt disease in flax and basil, respectively $(16,26)$. No specific association was found between formae speciales and VCGs associated with bulb and root rot of monocots in Iridaceae and Liliaceae. F. oxysporum f. sp. gladioli VCG 0340 does not appear to be closely related to F. oxysporum f. sp. lilii (VCG 0190), even though VCG 0340 is pathogenic to lily (3). As expected, putatively nonpathogenic isolates from lily that do not belong to VCG 0190 proved unrelated to this pathogenic VCG. The status of NRRL 26442 remains unresolved. Although NRRL 26442 was received as $F$. oxysporum f. sp. lilii, it is nonpathogenic to susceptible lily cv. Esther and is not a member of VCG 0190.

Six strains isolated from and nonpathogenic to carnation from the study of Aloi and Baayen (1) all belonged to clade 3, which does not contain $F$. oxysporum $\mathrm{f}$. sp. dianthi. Two of these strains isolated from the same carnation plant (NRRL 28369 and 28392), though vegetatively incompatible, proved to be phylogenetically related to each other. Two others (NRRL 26994 and 28376) belong to a putatively nonpathogenic VCG that is commonly found as an endophyte in the xylem of healthy carnations. This fungus is presently commercialized as a biocontrol agent against Fusarium wilt $(1,43)$. Apart from a minimal risk of parasexual or vegetative (horizontal) gene exchange with pathogenic strains encountered inside the xylem of carnation, these biocontrol strains are unlikely to become pathogenic.

The single cosmopolitan VCG 0021 of $F$. oxysporum f. sp. dianthi proved phylogenetically distinct from the remaining five 
TABLE 6. Kishino-Hasegawa likelihood analysis of constrained and unconstrained of trees from combined mitochondrial small subunit (mtSSU) rDNA and EF$1 \alpha$ data set

\begin{tabular}{lllrr}
\hline Tree $^{\mathrm{a}}$ & Tree length $^{\mathrm{b}}$ & $-\ln L$ & Difference $-\ln L$ & $\mathrm{SD}^{\mathrm{c}}$ \\
\hline MPT & 116 & $-2,713.11859$ & & \\
Fusarium oxysporum f. sp. asparagi & $123(+7)$ & $-2,766.47588$ & -53.35729 & 17.52455 \\
Fusarium oxysporum f. sp. dianthi & $121(+5)$ & $-2,755.24375$ & -42.12516 & 16.64345 \\
Fusarium oxysporum f. sp. gladioli & $133(+17)$ & $-2,840.23080$ & -127.11221 & 26.60986 \\
Fusarium oxysporum f. sp. lini & $126(+10)$ & $-2,789.46793$ & -77.64955 & 21.44588 \\
Fusarium oxysporum f. sp. opuntiarum & $116(+0)$ & $-2,714.74013$ & -1.62154 & 6.0115 \\
- & & & 0.47521 \\
\hline
\end{tabular}

${ }^{a}$ Monophyly constraints enforced with PAUP* were compared with the best most parsimonious tree (MPT).

${ }^{b}$ Includes autapomorphic characters. Numbers in parentheses represent the difference in length between MPT and constrained trees.

c Standard deviation of $\log$ likelihood.

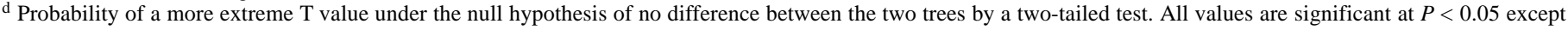
for the F. oxysporum f. sp. opuntiarum monophyly constraint.

VCGs that have restricted geographic distributions. The latter VCGs do not appear to have evolved from VCG 0021, even though this is the only sympatric VCG for VCGs 0025 and 0027 (restricted to the Netherlands) and VCG 0028 (strictly Australian) $(6,21)$.

Attempts to elucidate the VCG structure in $F$. oxysporum $\mathrm{f}$. sp. lini were largely unsuccessful. The self-incompatibility of several of the isolates from flax may have been due to prolonged subculturing of the isolates. Nevertheless, four distinct AFLP groups and three gene genealogy lineages were resolved in this forma specialis. Two of these exhibited restricted geographic distributions. Isolates of $F$. oxysporum f. sp. lini have been associated with wilt disease according to some authors, and with root rot according to others $(26,27)$. The possibility that only certain lineages may be able to incite wilt disease, in addition to cortical rot, deserves exploration.

Considerable phylogenetic diversity was found in $F$. oxysporum f. sp. opuntiarum, and most isolates formed single-member VCGs. The only large VCG was composed of isolates exclusively from a single nursery. This parallels VCG diversity in $F$. oxysporum $\mathrm{f}$. sp. asparagi, where numerous distinct VCGs occur, but none of these appears to have a selective advantage over the others $(8,14)$, a condition normally occurring in freely outcrossing populations. Indeed, Taylor et al. (47) recently presented evidence for the occurrence of recombination among clade 1 members of $F$. oxysporum f. sp. cubense by combining and reanalyzing data published by O'Donnell et al. (41), Koenig et al. (25), and Bentley et al. (7).

Although multiple mutation or transposition events may have led to the independent acquisition of pathogenicity to the same host in strains with a different phylogeny, other mechanisms may be involved as well. Parasexuality can occur in F. oxysporum (30) and may have contributed to lateral transfer of pathogenicity genes to distantly related strains. The same holds for sexuality, because vegetative incompatibility does not necessarily block the sexual cycle. A single cross between two isolates with different VCG genotypes could result in more than 1,000 progeny VCG genotypes (30), and pathogenicity genes could be partitioned in numerous VCGs. Many fungi may still have an infrequent sexual cycle, and there is no reason to assume that members of the FOC are an exception (47). Mating-type gene sequences recently have been found in all investigated strains of the currently examined formae speciales (C. Waalwijk, unpublished data). Horizontal transfer of pathogenicity genes on conditionally dispensable (supernumerary) chromosomes to related strains may also be involved (12). The apparent clustering of most of the VCGs of $F$. oxysporum f. spp. dianthi and lini in one subclade and those of $F$. oxysporum f. sp. opuntiarum in clade 1 is consistent with this hypothesis. In addition, horizontal gene transfer across species boundaries may explain why xylem-colonizing VCGs that cause wilt disease of carnation are found in $F$. oxysporum f. sp. dianthi as well as $F$. redolens f. sp. dianthi $(4,6)$, why asparagus root- and crown rot-associated VCGs exist in F. oxysporum f. sp. asparagi, $F$. redolens f. sp. asparagi, and $F$. proliferatum f. sp. asparagi $(13,14,20)$, and perhaps even why wilt disease-inducing formae speciales exist in F. udum (19), a member of the G. fujikuroi species complex (37).

The origin of pathogenic diversity and the potential of horizontal spread of pathogenicity genes and gene clusters among members of the FOC deserves further investigation. Horizontal (vegetative) spread of dispensable chromosomes carrying pathogenicity genes or gene clusters across evolutionary distinct lineages (12) might explain why basic pathogenicity to the same host occurs in different clades of the FOC. Such a mechanism, as yet purely speculative, could provide support for the existing concept of formae speciales as introduced by Snyder and Hansen (45), even if the overall evolutionary background of VCGs in a given forma specialis is heterogeneous. More probable, host specificity and pathogenicity genes in different VCGs of a forma specialis are dissimilar generally, rendering the forma specialis concept artificial and of little predictive value. The practical diagnostic value of such an artificial classification system will undoubtedly eventually prove inferior to a novel, VCG-based, and more natural system with greater predictive value than host specificity. Whether a correlation exists between lineages in gene and AFLP trees and the morphologically defined subgroups in section Elegans, as circumscribed by Wollenweber and Reinking (53), deserves further study.

\section{ACKNOWLEDGMENTS}

These investigations were supported in part by the Ministry of Agriculture, Fisheries and Nature Conservation of The Netherlands (DWK337). We thank M. Fiely, A. Garibaldi, G. Kalc-Wright, H. C. Kistler, G. Kroes, H. Löffler, and B. Manicom, as well as the curators of the culture collections for providing strains of the $F$. oxysporum complex. We also thank M. Hagenaar-De Weerdt and M. Förch for their excellent technical assistance.

\section{LITERATURE CITED}

1. Aloi, C., and Baayen, R. P. 1993. Examination of the relationships between vegetative compatibility groups and races in Fusarium oxysporum f. sp. dianthi. Plant Pathol. 42:839-850.

2. Appel, D. J., and Gordon, T. R. 1994. Local and regional variation in populations of Fusarium oxysporum from agricultural field soils. Phytopathology 84:786-791.

3. Baayen, R. P., Förch, M. G., Waalwijk, C., Bonants, P. J. M., Löffler, H. J. M., and Roebroeck, E. J. A. 1998. Pathogenic, genetic, and molecular characterization of Fusarium oxysporum f. sp. lilii. Eur. J. Plant Pathol. 104:887-894.

4. Baayen, R. P., and Gams, W. 1988. The Elegans fusaria causing wilt disease of carnation. I. Taxonomy. Neth. J. Plant Pathol. 94:273-278.

5. Baayen, R. P., and Rijkenberg, F. H. J. 1999. Fine structure of the early interaction of lily roots with Fusarium oxysporum f. sp. lilii. Eur. J. Plant Pathol. 105:431-443.

6. Baayen, R. P., Van Dreven, F., Krijger, M. C., and Waalwijk, C. 1997. Genetic diversity in Fusarium oxysporum f. sp. dianthi and Fusarium redolens f. sp. dianthi. Eur. J. Plant Pathol. 103:395-408.

7. Bentley, S., Pegg, K. G., Moore, N. Y., Davis, R. D., and Buddenhagen, I. W. 1998. Genetic variation among vegetative compatibility groups of Fusarium oxysporum f. sp. cubense analyzed by DNA fingerprinting. 
Phytopathology 88:1283-1293.

8. Blok, W. J., and Bollen, G. J. 1997. Host specificity and vegetative compatibility of Dutch isolates of Fusarium oxysporum f. sp. asparagi. Can. J. Bot. 75:383-393.

9. Brown, J. K. M. 1996. The choice of molecular marker methods for population genetic studies of plant pathogens. New Phytol. 133:183-195.

10. Bruhn, C. 1956. Untersuchungen über die Fusarium-Krankheit der Gladiolen. Phytopathol. Z. 25:1-38.

11. Chiocchetti, A., Ghignone, S., Minuto, A., Gullino, M. L., Garibaldi, A., and Migheli, Q. 1999. Identification of Fusarium oxysporum f. sp. basilici isolated from soil, basil seed, and plants by RAPD analysis. Plant Dis. 83:576-581.

12. Covert, S. F. 1998. Supernumerary chromosomes in filamentous fungi. Curr. Genet. 33:311-319.

13. Elmer, W. H. 1995. A single mating population of Gibberella fujikuroi (Fusarium proliferatum) predominates in asparagus fields in Connecticut, Massachusetts, and Michigan. Mycologia 87:68-71.

14. Elmer, W. H., and Stephens, C. T. 1989. Classification of Fusarium oxysporum f. sp. asparagi into vegetatively compatible groups. Phytopathology 79:88-93.

15. Fiely, M. B., Correll, J. C., and Morelock, T. E. 1995. Vegetative compatibility, pathogenicity, and virulence diversity of Fusarium oxysporum recovered from spinach. Plant Dis. 79:990-993.

16. Gamliel, A., Katan, T., Yunis, H., and Katan, J. 1996. Fusarium wilt and crown rot of sweet basil: Involvement of soilborne and airborne inoculum. Phytopathology 86:56-62.

17. Gams, W., Klamer, M., and O’Donnell, K. 1999. Fusarium miscanthi sp. nov. from Miscanthus litter. Mycologia 91:263-268.

18. Gerlach, W. 1972. Fusarium rot and other fungal diseases of horticulturally important cacti in Germany. Phytopathol. Z. 74:197-217.

19. Gerlach, W., and Nirenberg, H. I. 1982. The genus Fusarium: A pictorial atlas. Mitt. Biol. Bundesanst. Land-Forstwirtsch. Berl.-Dahlem 209:1406.

20. Gerlach, W., and Pag, H. 1961. Fusarium redolens Wr., seine phytopathologische Bedeutung und eine an Dianthus-arten gefäßparasitäre form (F. redolens Wr. f. dianthi Gerlach). Phytopathol. Z. 42:349-361.

21. Kalc Wright, G. F., Guest, D. I., Wimalajeewa, D. L. S., and Van Heeswijck, R. 1996. Characterisation of Fusarium oxysporum isolated from carnation based on pathogenicity, vegetative compatibility and random amplified polymorphic DNA (RAPD) assay. Eur. J. Plant Pathol. 102:451-457.

22. Katan, T. 1999. Current status of vegetative compatibility groups in Fusarium oxysporum. Phytoparasitica 27:51-64.

23. Katan, T., Gamliel, A., and Katan, J. 1996. Vegetative compatibility of Fusarium oxysporum from sweet basil in Israel. Plant Pathol. 45:656-661.

24. Kistler, H. C. 1997. Genetic diversity in the plant-pathogenic fungus Fusarium oxysporum. Phytopathology 87:474-479.

25. Koenig, R. L., Ploetz, R. C., and Kistler, H. C. 1997. Fusarium oxysporum $\mathrm{f}$. sp. cubense consists of a small number of divergent, globally distributed clonal lineages. Phytopathology 87:915-923.

26. Kroes, G. M. L. W. 1997. Aspects of resistance of flax and linseed (Linum usitatissimum) to Fusarium oxysporum f. sp. lini. Ph.D. thesis. Wageningen Agricultural University, Wageningen, Netherlands.

27. Kroes, G. M. L. W., Baayen, R. P., and Lange, W. 1998. Histology of root rot of flax seedlings (Linum usitatissimum) infected by Fusarium oxysporum f. sp. lini. Eur. J. Plant Pathol. 104:725-736.

28. Kroes, G. M. L. W., Löffler, H. J. M., Parlevliet, J. E., Keizer, L. C. P., and Lange, W. 1999. Interactions of Fusarium oxysporum f. sp. lini, the flax wilt pathogen, with flax and linseed. Plant Pathol. 48:491-498.

29. Leslie, J. F. 1991. Mating populations in Gibberella fujikuroi (Fusarium section Liseola). Phytopathology 81:1058-1060.

30. Leslie, J. F. 1993. Fungal vegetative compatibility. Annu. Rev. Phytopathol. 31:127-151.

31. Massey, L. M. 1926. Fusarium rot of gladiolus corms. Phytopathology 16:509-523.

32. Mayer, D., Mithen, R., Lewis, B. G., Vos, P., and Oliver, R. P. 1997. The use of AFLP fingerprinting for the detection of genetic variation in fungi. Mycol. Res. 100:1107-1111.

33. Mes, J. J., Van Doorn, J., Roebroeck, E. J. A., Van Egmond, E., Van Aartrijk, J., and Boonekamp, P. M. 1994. Restriction fragment length polymorphisms, races and vegetative compatibility groups within a worldwide collection of Fusarium oxysporum f. sp. gladioli. Plant Pathol. 43:362-370.

34. Mes, J. J., Weststeijn, E. A., Herlaar, F., Lambalk, J. J. M., Wijbrandi, J., Haring, M. A., and Cornelissen, B. J. C. 1999. Biological and molecular characterization of Fusarium oxysporum $\mathrm{f}$. sp. lycopersici divides race 1 isolates into separate virulence groups. Phytopathology 89:156-160.

35. Nirenberg, H. I., and Aoki, T. 1997. Fusarium nisikadoi, a new species from Japan. Mycoscience 38:329-333.

36. Nirenberg, H. I., and O'Donnell, K. 1998. New Fusarium species and combinations within the Gibberella fujikuroi species complex. Mycologia 90:434-458.

37. O'Donnell, K., and Cigelnik, E. 1997. Two divergent intragenomic rDNA ITS2 types within a monophyletic lineage of the fungus Fusarium are nonorthologous. Mol. Phylo. Evol. 1:1-14.

38. O'Donnell, K., and Cigelnik, E. 1999. A DNA sequence-based phylogenetic structure for the Fusarium oxysporum complex. Phytoparasitica 27:69.

39. O’Donnell, K., Cigelnik, E., and Nirenberg, H. I. 1998. Molecular systematics and phylogeography of the Gibberella fujikuroi species complex. Mycologia 90:465-493.

40. O'Donnell, K., Gherbawy, Y., Schweigkofler, W., Adler, A., and Prillinger, H. 1999. Phylogenetic analyses of DNA sequence and RAPD data compared in Fusarium oxysporum and related species from maize. J. Phytopathol. 147:445-452.

41. O’Donnell, K., Kistler, H. C., Cigelnik, E., and Ploetz, R. C. 1998. Multiple evolutionary origins of the fungus causing Panama disease of banana: Concordant evidence from nuclear and mitochondrial gene genealogies. Proc. Natl. Acad. Sci. USA 95:2044-2049.

42. O'Neill, N. R., van Berkum, P., Lin, J. J., Kuo, J., Ude, G. N., Kenworthy, W., and Saunders, J. A. 1997. Application of amplified restriction fragment length polymorphism for genetic characterization of Colletotrichum pathogens of alfalfa. Phytopathology 87:745-750.

43. Postma, J., and Luttikholt, A. J. G. 1996. Nonpathogenic Fusarium isolates from carnation suppressing wilt caused by $F$. oxysporum f. sp. dianthi. Med. Fac. Landbouww. Univ. Gent 61/2b:499-505.

44. Roebroeck, E. J. A., and Mes, J. J. 1992. Physiological races and vegetative compatibility groups within Fusarium oxysporum f. sp. gladioli. Neth. J. Plant Pathol. 98:57-64.

45. Snyder, W. C., and Hansen, H. N. 1940. The species concept in Fusarium. Am. J. Bot. 27:64-67.

46. Tantaoui, A., Ouinten, M., Geiger, J. P., and Fernandez, D. 1996. Characterization of a single clonal lineage of Fusarium oxysporum f. sp. albedinis causing Bayoud disease of date palm in Morocco. Phytopathology 86:787-792.

47. Taylor, J. W., Jacobson, D. J., and Fisher, M. C. 1999. The evolution of asexual fungi: Reproduction, speciation and classification. Annu. Rev. Phytopathol. 37:197-246.

48. Vakalounakis, D. J., and Fragkiadakis, G. A. 1999. Genetic diversity of Fusarium oxysporum isolates from cucumber: Differentiation by pathogenicity, vegetative compatibility, and RAPD fingerprinting. Phytopathology 89:161-168.

49. Vos, P., Hogers, R., Bleeker, M., Reijans, M., van de Lee, T., Hornes, M., Frijters, A., Pot, J., Peleman, J., Kuiper, M., and Zabeau, M. 1995. AFLP: A new technique for DNA fingerprinting. Nucleic Acids Res. 23:4407-4414

50. Waalwijk, C., Baayen, R. P., De Koning, J. R. A., and Gams, W. 1996. Ribosomal DNA analyses challenge the status of Fusarium sections Liseola and Elegans. Sydowia Ann. Mycol. 48:90-104.

51. Waalwijk, C., De Koning, J. R. A., Baayen, R. P., and Gams, W. 1996. Discordant groupings of Fusarium spp. from sections Elegans, Liseola and Dlaminia based on ribosomal ITS1 and ITS2 sequences. Mycologia 88:316-328.

52. White, T. J., Bruns, T., Lee, S., and Taylor, J. 1990. Amplification and direct sequencing of fungal ribosomal RNA genes for phylogenetics. Pages 315-322 in: PCR protocols: A guide to methods and applications. M. A. Innis, D. H. Gelfand, J. J. Sninsky and T. J. White, eds. Academic Press, San Diego, CA.

53. Wollenweber, H. W., and Reinking, O. A. 1935. Die Fusarien. Ihre Beschreibung, Schadwirkung und Bekämpfung. P. Parey, Berlin. 